\title{
HIV-1 reverse transcriptase inhibitory activity of Aerva lanata plant extracts
}

\author{
Rajendra Prasad Gujjeti", Sainath Namthabad, Estari Mamidala \\ From 2nd International Science Symposium on HIV and Infectious Diseases (HIV SCIENCE 2014) \\ Chennai, India. 30 January - 1 February 2014
}

\section{Background}

HIV-1 reverse transcriptase (HIV-1 RT) is an essential enzyme for the replication cycle of HIV. HIV-1 RT inhibitors have been extensively investigated for their antiHIV properties. However, emergence of HIV drug resistance and side effects are the main reasons for failure of anti-HIV therapy. The aim of the present study was to evaluate the HIV reverse transcriptase inhibitory activity of Aerva lanata plant extracts.

\section{Methods}

Extracts were prepared from dried roots in different solvents. Peripheral Blood Mononuclear Cells (PBMCs) were isolated from healthy donors by ficoll-hypaque density gradient centrifugation method. A toxicity study was performed on all crude extracts among PBMCs by MTT assay. HIV-1 RT inhibition activity of the all solvent extracts of $A$. lanata was determined by a HIV-1 Reverse Transcriptase activity assay.

\section{Results}

All the five solvent crude extracts of $A$. lanata were non cytotoxic up to $0.75 \mathrm{mg} / \mathrm{mL}$ concentration in PBMCs. Chloroform and methanol extracts shows highest inhibition of recombinant HIV RT ( $91 \%$ and $89 \%$ respectively) at $1 \mathrm{mg} / \mathrm{mL}$ concentration. This strong inhibitory effect was confirmed by their $\mathrm{IC}^{50}$. More than $50 \%$ inhibition of HIV RT shows from 0.03 to $1 \mathrm{mg} / \mathrm{mL}$ concentrations of all extracts.

\section{Conclusion}

Experimental results thus suggested that the A. lanata plant extracts which have been tested in the present study exert their anti-HIV activity via inhibition of HIV Reverse

* Correspondence: prasadzoology@gmail.com

Infectious Diseases Research Lab, Department of Zoology, Kakatiya University, Warangal, Andhra Pradesh, India
Transcriptase activity. However, in order to assess the usefulness of this herb, it is necessary to isolate the active principle (s) from the crude extracts.

Published: 27 May 2014

doi:10.1186/1471-2334-14-S3-P12

Cite this article as: Gujjeti et al.: HIV-1 reverse transcriptase inhibitory activity of Aerva lanata plant extracts. BMC Infectious Diseases 2014 14(Suppl 3):P12.
Submit your next manuscript to BioMed Central and take full advantage of:

- Convenient online submission

- Thorough peer review

- No space constraints or color figure charges

- Immediate publication on acceptance

- Inclusion in PubMed, CAS, Scopus and Google Scholar

- Research which is freely available for redistribution

\section{() Biomed Central}

